\title{
The Effects of Young Children's Temperament on Parenting Stress of Mothers: Mediating Effects of the Parental Satisfaction
}

\author{
Jong Hee Choi ${ }^{1}$, Mi-Kyung Choi ${ }^{2}$ \\ Department of Counseling for Children, Duksung Women's University, Seoul, Korea ${ }^{1}$ \\ 유아의 기질이 어머니의 양육스트레스에 미치는 영향: \\ 부모역할만족도의 매개효과 \\ 최종희 ${ }^{1}$, 최미경 ${ }^{2}$ \\ 덕성여자대학교 문화산업대학원 아동상담전공 ${ }^{1}$ 덕성여자대학교 아동가족학과 ${ }^{2}$
}

Department of Human Development and Family Studies, Duksung Women's University, Seoul, Korea ${ }^{2}$

Objective: The main purpose of this study was to examine the relationships between children's temperament, parental satisfaction, and parenting stress of mothers with young children.

Methods: The participants comprised 326 mothers with young children in Seoul and Gyeonggi Province. The subjects completed questionnaires on children's temperament, parental satisfaction, and parenting stress. The data were analyzed by frequency analysis, calculation of Cronbach's $\alpha$, descriptive statistic analysis, Pearson's correlation coefficients, multiple regression analysis, and hierarchical multiple regression analysis. To analyze the collected data, SPSS 22.0 program was used. Results: First, children's temperament (adaptive temperament/active temperament/regular temperament) had an effect on parenting stress (parental distress/parent-child dysfunctional interaction/difficult child). Second, parental satisfaction (general satisfaction/parent-child relationship/spousal support/parental role conflict/child support) had effect on parenting stress (parental distress/parent-child dysfunctional interaction/difficult child). Third, children's temperament (adaptive temperament/active temperament/regular temperament) had an effect on parental satisfaction (general satisfaction/parent-child relationship/spousal support/parental role conflict/child support). Fourth, the mediating effect of parental satisfaction (general satisfaction/ parent-child relationship/parental role conflict) was found in the relationship between children's temperament (adaptive temperament/active temperament/regular temperament) and parenting stress (parental distress/parent-child dysfunctional interaction/difficult child).

Conclusion: These results indicate parental satisfaction plays an important role in children's temperament and parenting stress of mothers. In addition, this study also shows children's temperament directly affects parenting stress of mothers. Therefore, this study will be useful for developing parental education programs for mothers.

Keywords: children's temperament, parenting stress, parental satisfaction

Corresponding Author: Mi-Kyung Choi, Department of Human Development and Family Studies, Duksung Women's University, 33 Samyangro 144-gil, Dobong-gu, Seoul, Korea

E-mail: dmkchoi@duksung.ac.kr (c) The Korean Association of Child Studies

This is an Open Access article distributed under the terms of the Creative Commons Attribution Non-Commercial License (http:// creativecommons.org/licenses/by-nc/4.0) which permits unrestricted noncommercial use, distribution, and reproduction in any medium, provided the original work is properly cited. 


\section{서론}

통계청의 인구동향조사에 따르면 우리나라 합계출산율은 1994년에는 1.656명, 2000년에는 1.467명, 2014년에는 1.205 명, 2016년에는 1.172명으로 점차 감소한 것으로 나타났다 (Statistics Korea, 2017). 또한 통계청의 인구총조사에 따르면 우 리나라 평균 가구원 수는 2000년은 3.1명, 2005년은 2.9명이 며(Statistics Korea, 2007) 2010년은 2.7명(Statistics Korea, 2011), 2015년은 2.5명으로(Statistics Korea, 2017) 감소하였다. 이는 우리나라의 핵가족이 증가하고 있다는 것을 의미하며 현대사 회의 급격한 경제적 변화, 맞벌이 가족의 증가와 함께 자녀 양 육에 따른 많은 문제점들로 나타나고 있다. 즉, 급격한 경제적 변화, 취업여성의 급증, 핵가족화로 가족지지 체제가 축소됨 에 따라 다른 가족원의 도움 없이 부부 둘만이 자녀양육을 수 행함으로써 겪는 여러 어려움에 직면해있다. 더욱이 자녀 양 육에 대한 부모의 책임은 증가하고 부모역할에 대한 요구수준 이 높아짐에 따라 자녀양육으로 인한 스트레스는 그 어느 때 보다 높다(Jung, 2016).

부모가 양육스트레스를 느끼게 되면 심리적 부담감은 물론 자녀에 대한 태도, 자녀와의 상호작용에 부정적 영향을 미치 기 때문에 부모로서의 적응에 부정적인 결과를 나타내며, 양 육에 대한 부모의 관심을 약화시켜 역기능적이고 부정적인 양 육행동을 하게 된다(Abidin, 1990). 실제로 양육스트레스가 높 은 부모의 경우 부정적 양육행동을 했으며, 온정적 양육행동 을 적게 보였고(Slack, Holl, McDaniel, Yoo, \& Bolger, 2004) 자 녀들의 정서 및 사회성 발달에도 부정적인 영향을 미쳤다 $(\mathrm{H}$. M. Kim \& Doh, 2004). 이처럼 양육스트레스는 부모 자신뿐만 아니라 양육태도와 부모자녀관계에 까지 영향을 끼칠 수 있다 는 점에서 사회적인 관심이 요구된다. 그럼에도 불구하고 우 리 사회에서 자녀양육은 어머니의 역할이라는 전통적인 가족 가치관으로 인해 어머니 혼자서 자녀를 양육하는 경우가 많다 (K. H. Kim \& Cho, 2000). 이와 같이 자녀양육의 일차적 책임 이 주로 어머니에게 부과되고 있으며, 또한 어머니들 스스로 가 주양육자라는 믿음을 가지고 있어 우리나라의 어머니들에 게 양육스트레스는 더욱 큰 어려움이 되고 있다.

어머니의 양육스트레스에 영향을 미치는 요인은 다양하 나 크게 자녀의 요인, 어머니의 요인, 사회적 요인으로 구분할 수 있다. 자녀의 요인으로는 기질, 사회성 등이 포함되며, 어 머니의 요인으로는 자기효능감, 부모역할관이 있고 사회적 요인으로는 결혼만족도, 가족의 지지 등이 연구되었다(K. M. Park, 2014). 기질이란 생의 초기부터 나타나는 개인적 성향,
행동 양식, 또는 영아의 정서적 반응으로써 이후의 아동 성격 형성에 있어 기초가 되는 특성이다(Y.-J. Lee, 2014). 기질에 대 한 몇몇 연구들은(Partridge \& Lerner, 2007; Rothbart \& Bates, 2006; Thomas \& Chess, 1996) 기질이 고정된 개념이 아닌 그 들이 속한 환경과의 상호 영향을 주고 받으며 발전되고 변화 할 수 있는 특징을 갖는다고 주장한다. 더욱이 근래에 들어 환 경적 맥락이 중요하게 대두되면서 Thomas와 Chess (1977)의 기질 연구가 가장 포괄적이고 대표적 유형으로 꼽히고 있다. 따라서 기질이 환경과 상호 영향을 주고 받는다는 사실을 고 려해볼 때 기질은 어머니의 양육스트레스에 중요한 변인임 을 알 수 있다. 어머니의 양육스트레스와 자녀의 기질 간의 관 계를 살펴보면 까다로운 기질을 가진 유아들이 양육스트레 스를 증가시키는 것으로 나타났다(Coplan, Bowker, \& Cooper, 2003; Kalifa, 2013). 또한 유아의 기질이 까다롭거나 높은 활 동성을 보이는 경우, 어머니는 양육과 관련된 높은 스트레스 를 경험했다(Y. Y. Jo, 2014; Y. S. Jo \& Jung, 2000; Nam, 2003; S. Y. Park, Jun, \& Han, 1996; Shin, 2011). 이처럼 자녀의 기질적 특성은 어머니의 스트레스에 중요한 변인임을 알 수 있다. 특 히, 기질 안정성은 영아기에 크게 증가하여 3세 무렵 가장 높 은 수준으로 나타나지만 이후에는 안정성이 더 이상 크게 증 가하지 않고 유아기보다 다소 낮은 수준으로 유지된다(Robert $\&$ Delvecchio, 2000). 그리고 유아기에 측정된 특정 기질적 특성이 이 후의 성격 특성을 예측하는 연구들은(Bosquet \& Egeland, 2006; Kagan, Snidman, Kahn, \& Townsley, 2007) 유아 기 기질에 관한 연구가 필요함을 보여준다. 또한 유아기는 정 서, 심리적 발달의 중요한 시기로 아동과 부모 간의 정서적 변 화가 일어나며 깊은 상호관계를 맺기 때문에(Hockenberry \& Winkelstein, 2004), 이 시기의 학문적 관심이 요구된다. 그러나 국내연구의 경우 유아기 보다 영아, 걸음마기 자녀의 기질과 부모의 양육을 주제로 한 연구가 상대적으로 많다(Choi, 2008; Y. Y. Jo, 2014; Y.-E. Lee, Kang, Park, Hwang, \& Moon, 2003). 따 라서 본 연구에서는 발달적으로 어머니의 영향력이 큰 유아기 를 대상으로 자녀의 기질이 어머니의 양육스트레스에 미치는 영향을 조사하였다.

다음으로 어머니의 양육스트레스에 영향을 미치는 요인 가 운데 유아의 발달에 영향력이 큰 것으로 알려지고 있는 어머 니의 요인을 고려할 수 있다. 자녀를 키우면서 겪게 되는 어머 니의 양육스트레스는 자녀를 양육하면서 느끼는 보람과 기 쁨과 같은 심리적 만족도에 의해 영향을 받는 것으로 나타났 다. 즉, 부모가 자녀를 양육하면서 느끼는 만족감은 일상적 긴 장과 갈등요소를 경감시켜 성인이 지각하는 전반적인 생활 
만족도에 영향을 끼치는 동시에 부, 모, 자녀를 포함하는 가 족체계의 긍정적인 형성을 위해서도 매우 중요한 요인이다 (Guidubaldi \& Cleminshaw, 1989). 실제로 부모역할에 대한 만 족도가 낮을수록 높은 스트레스를 경험하고 있는 것으로 나타 났다(Song \& Song, 2007). 더욱이 높은 부모역할만족이 자녀 를 양육하면서 치러야 할 경제적 부담, 자유의 박탈, 훈육의 어 려움을 상쇄한다(Cho \& Hyun, 1994). 어머니가 자녀를 양육 하면서 느끼는 스트레스는 부모역할에 관한 어머니 개인의 심 리적 만족도와 관련이 클 수 있다. 따라서 유아를 양육하는 어 머니의 양육스트레스와 관련된 변인으로써 부모역할만족도 가 주목된다. 그러나 부모역할만족도를 양육스트레스와 관련 지어 직접적으로 실시한 연구는 거의 찾아보기 어려우며 유사 한 변인으로 결혼만족도, 양육효능감, 모성역할자신감, 부모 역할자긍심과 같은 변인과 양육스트레스를 다룬 연구가 소수 있을 뿐이다(H. M. Kim \& Doh, 2004; M.-J. Kim, Doh, Shin, \& Choi, 2013; Kwon, Kim, Kim, \& Jang, 2006; J. Lee \& Jang, 2008; Y.-E. Lee et al., 2003; Seo \& Lee; 2013). 따라서 본 연구에서는 취학전 연령의 유아를 둔 부모의 역할 부담감이 크다는 점을 고려하여, 이 시기 자녀를 둔 어머니를 대상으로 어머니의 부 모역할만족도가 양육스트레스에 미치는 영향을 조사하였다.

한편, 유아의 기질은 어머니의 부모역할만족도와 관련이 있다고 보고되어 어머니가 지각한 아동의 기질 유형에 따라 부모역할만족도에 차이가 생겼고 대체로 순한 아동의 어머니 가 느리거나 까다로운 아동의 어머니보다 부모역할에 대한 만 족도가 높았다(Y. Lee \& Jo, 2002). 또한 부모가 자녀의 기질을 좋아하고 이를 수용할 때 부모는 자녀에 대한 높은 만족도를 보이며 높은 만족도로 인해 자녀에게 보다 적합하고 긍정적 인 양육태도를 보였다(Jin, 1993). 위와 같은 결과는 영아에 대 한 연구에서도 나타나 어머니가 영아의 기질에 대해 긍정적으 로 생각할수록 어머니 역할수행에 대한 자신감이 높았다(Y.-E. Lee et al., 2003). 이와 같이 자녀의 기질은 어머니의 부모역할 만족도에 영향을 미치는 중요한 변인임을 확인할 수 있다. 그 러나 실제로 유아의 기질과 어머니의 부모역할만족도에 관한 국내 연구는 소수에 불과하다. 또한 자녀의 기질 관련 연구는 신생아와 영아를 대상으로 한 연구가 대부분이다(Choi, 2008; Y. Y. Jo, 2014; Y.-E. Lee et al., 2003; Seo \& Lee, 2013). 그러나 교 육과 훈육이 활발히 나타나는 유아기 자녀의 기질적 특성 역 시, 부모역할과 관련될 수 있음을 고려하여 이 시기 자녀의 기 질과 부모역할만족도를 살펴볼 필요가 있다. 따라서 본 연구 에서는 유아의 기질이 어머니의 부모역할만족도에 미치는 영 향을 조사하였다.
지금까지 살펴본 바와 같이 유아의 기질과 어머니의 부모 역할만족도는 각각 양육스트레스에 영향을 미칠 뿐 아니라 유 아의 기질은 어머니의 부모역할만족도에 영향을 미치는 것으 로 예상할 수 있다. 이를 직접적으로 조사한 선행연구는 찾아 보기 어렵지만 자녀의 기질과 양육스트레스 간의 관계에서 부 모역할에 대한 자신감, 자녀 양육에 대한 자신감, 자녀 양육에 대한 만족도와 같은 어머니의 심리적 특성을 조사한 연구들은 위의 가정을 뒷받침한다. 즉, 유아가 활동성이 높고 적응성이 낮을수록 어머니는 양육에 대한 자신감을 잃게 되어 양육효능 감이 낮아지고 자녀에게 부정적인 양육행동을 할 가능성이 높 았다(M.-J. Kim et al., 2013). 또한 쉽게 화를 내고 끓임없이 움 직이는 아동의 경우, 어머니는 부모로서의 역할을 더 힘들게 느끼고 스트레스를 더 많이 지각하였고(S. Y. Park et al., 1996), 아동의 까다로운 기질적 요인이 양육스트레스로 작용하여 어 머니에게 양육에 대한 신념과 자신감 형성을 방해했다(Y.-J. Lee, 2014). 그러나 유아의 기질특성과 어머니의 부모역할만 족도, 양육스트레스 세 변인을 함께 고려한 선행연구는 찾아 보기 어렵다. 자녀를 직접 돌보는 양육자의 스트레스가 정서, 사회성 발달이 활발히 이루어지는 유아기 자녀에게 미치는 영 향이 크다는 점을 고려할 때, 유아기의 기질과 양육스트레스 간의 관계에서 부모역할만족도가 차지하는 역할을 조사할 필 요가 있다. 따라서 본 연구에서는 유아의 기질과 양육스트레 스 간의 관계에서 부모역할만족도의 매개효과를 살펴보았다.

이상을 종합하면, 유아의 기질 및 어머니의 부모역할만족 도와 양육스트레스는 서로 밀접한 관련성이 있음을 예측할 수 있다. 이에 본 연구는 유아의 기질 및 어머니의 부모역할만족 도가 어머니의 양육스트레스에 미치는 영향력을 살펴보았다. 이와 동시에 유아의 기질과 어머니의 양육스트레스 간의 관계 에서 부모역할만족도의 매개효과를 조사했다. 본 연구의 연구 문제는 다음과 같다.

\section{연구문제 1}

유아의 기질은 어머니의 양육스트레스에 어떤 영향을 미치는가?

\section{연구문제 2}

어머니의 부모역할만족도는 양육스트레스에 어떤 영향을 미치 는가?

\section{연구문제 3}

유아의 기질은 어머니의 부모역할만족도에 어떤 영향을 미치 는가? 


\section{연구문제 4}

부모역할 만족도는 유아의 기질과 어머니의 양육스트레스 간 의 관계를 매개하는가?

\section{연구방법}

\section{연구대상}

본 연구의 대상은 서울시와 경기도에 거주하는 3세 5세의 자녀를 둔 어머니 326명이었다. 본 연구의 대상을 유아기의 어머니로 선정한 이유는, 유아의 발달에는 유아 개인의 특성 및 유아를 둘러싼 다양한 환경적 요인들이 영향을 미칠 수 있 는데, 그 중 부모는 유아가 태어나면서 최초로 접하는 환경으 로 어머니는 유아와 밀접하게 관련되는 일차적 환경요인으 로, 유아의 발달적 결과에 영향을 미치는 주요 요인이기 때 문이다(J. M. Kim \& Kim, 2015). 연구대상자의 사회인구학 적 특성을 살펴보면, 연구에 참여한 유아의 성별 구성은 남 아가 145 명(44.5\%), 여아가 181 명(55.5\%)이었다. 유아의 연 령은 5세가 120 명(36.8\%)으로 가장 많았으며 3세가 105 명 (32.2\%), 4세가 101 명 $(31.0 \%)$ 순으로 나타났다. 유아의 출생 순위는 첫째가 210 명 $(64.4 \%)$ 으로 가장 많았으며 둘째가 99 명(30.4\%), 셋째 이상이 17 명(5.2\%) 순으로 나타났다. 어머니 의 연령은 36-40세가 175 명(53.7\%)으로 가장 많았으며 30-35 세가 76명(23.3\%), 41-45세가 69명(21.2\%), 46세 이상이 6명 $(1.8 \%)$ 순으로 나타났다. 어머니의 학력은 대학교 졸업이 261 명(80.1\%), 고등학교 졸업이 32명(9.8\%), 대학원 졸업 이상이 33 명(10.1\%)으로 나타났다. 직업은 전업주부가 157 명(48.1\%) 으로 가장 많았으며 회사원이 86명(26.4\%) 순으로 나타났고 그 다음으로는 전문직이 41 명(12.6\%), 기타 27명(8.3\%), 공무 원이 10 명(3.1\%), 자영업이 5 명 $(1.5 \%)$ 으로 나타났다. 가정의 월소득은 400만원 이상이 203명(62.2\%), 300-400만원 미만이 74명(22.7\%), 200-300만원 미만이 40명(12.3\%), 100-200만원 미만이 9명 $(2.8 \%)$ 순으로 나타났다.

\section{연구도구}

본 연구의 측정도구는 유아의 기질을 비롯하여, 어머니의 부 모역할만족도 그리고 어머니의 양육스트레스를 측정하는 세 가지 척도로 구성되었고 모든 척도는 어머니에 의해 보고되 었다.

\section{유아의 기질}

본 연구에서 사용한 유아의 기질 질문지는 Thomas와 Chess (1977)의 기질차원 검사(DOTS-R: Windle \& Lerner, The Revised Dimensions of Temperament Survey, 1986)를 Suh와 Yi (2009)가 수정 보완한 척도를 사용하였다. 본 척도는 하위요인 별로 적응적 기질 9문항, 활발한 기질 12 문항, 규칙적 기질 9 문항 총 30문항으로 이루어졌다. 각 문항들은 1-4점의 4점 척 도로 구성되어 있으며, 각 문항은 대개 그렇지 않다(1점), 그렇 지 않은 편이다(2점), 그런 편이다(3점), 대개 그렇다(4점)의 점 수를 주었다. 구체적인 설문 문항의 예로 적응적 기질은 "우 리 아이는 새로운 상황을 좋아한다.", 활발한 기질은 “우리 아 이는 이리저리 많이 돌아다닌다.”, 규칙적 기질은 "우리 아이 는 매일 밤 거의 일정한 시간 동안 잠을 잔다.”와 같은 문항이 포함된다. 본 연구에서 유아의 기질 하위 영역별 신뢰도 계수 (Cronbach's $\alpha$ )는 적응적 기질이 .76, 활발한 기질이 .74, 규칙 적 기질이 .81 으로 나타났다.

\section{어머니의 부모역할만족도}

어머니의 부모역할만족도는 Cho와 Hyun (1994)의 부모역할 만족도 척도를 사용하였다. 이 척도는 일반적 만족도 11 문항, 부모자녀관계 10 문항, 배우자 지지 10 문항, 부모역할갈등 11 문항, 자녀의 지지 6 문항의 5 개 하위요인을 포함하고 있으며 총 48 문항으로 구성되어 있다. 각 문항은 1-4점의 4점 척도로 구성되어 있으며 각 문항은 전혀 그렇지 않다(1점), 대체로 그 렇지 않다(2점), 약간 그렇다(3점), 매우 그렇다(4점)의 점수를 주었다. 구체적인 설문 문항의 예로 일반적 만족도는 "나는 아 이가 성장해감을 볼 때 뿌듯하다.”, 부모자녀관계는 “나는 아 이와 충분한 시간을 보낸다고 생각되어 만족한다.”, 배우자 지지는 "남편이 자녀양육에 참여하는 정도에 대하여 만족한 다.", 부모역할갈등은 "아이로 인해 일어나는 일들 때문에 화 가 나고 짜증스럽다.”, 자녀의 지지는 "어려운 상황에 처할 때 아이는 나를 도와준다.”와 같은 문항이 있다. 본 연구에서 어 머니의 부모역할만족도 하위 영역별 신뢰도 계수(Cronbach's $\alpha$ )는 일반적 만족도 .85 , 부모자녀관계 .87, 배우자지지 .94, 부 모역할갈등 .85 , 자녀의 지지 .82 이었다.

\section{어머니의 양육스트레스}

어머니의 양육스트레스는 Abidin (1990)의 부모 양육스트레스 
척도(Parenting Stress Index/Short Form [PSI/SF])를 H. M. Kim 과 Doh (2004)가 개정한 척도를 사용하였다. 본 검사 척도는 부모의 고통, 부모-자녀간 역기능적 상호작용, 자녀의 특성 세 가지 하위요인으로 각각 12 문항씩 총 36 문항으로 구성되어 있다. 각 문항은 1-5점의 5점 척도로 구성되어 있으며 각 문항 은 거의 그렇지 않다(1점), 그렇지 않은 편이다(2점), 보통이다 (3점), 그런 편이다(4점), 매우 그렇다(5점)의 점수를 주었다. 구체적인 설문 문항의 예로 부모의 고통은 "나는 부모로서의 책임감에 얽매여 있는 느낌이 든다.”, 부모-자녀간 역기능적 상호작용은 "우리 아이는 나를 기분 좋게 하는 일들을 거의 하 지 않는다.", 자녀의 특성은 “우리 아이는 정말로 나를 많이 괴 롭히는 몇 가지가 있다.”와 같은 문항이 있다. 본 연구에서 어 머니의 부모역할만족도 하위 영역별 신뢰도 계수(Cronbach's $\alpha)$ 는 부모의 고통 .87 , 부모-자녀간 역기능적 상호작용 .86 , 자 녀의 특성 .89 이었다.

\section{조사절차 및 자료분석}

본 연구의 조사는 2015년 12월부터 2016년 1월까지 서울시 D, $\mathrm{S}, \mathrm{Y}$ 구와 경기도에 위치한 국공립, 직장, 민간 및 가정보육 시 설과 유치원(유치원: 1 기관, 어린이집: 7 기관)에 재원 중인 3 세 5세의 유아기 자녀를 둔 어머니를 대상으로 실시하였다. 본 연구를 수행하기 위해 사전에 해당 유아교육기관에 연구의 취 지와 내용을 설명하여 협조를 구한 후 참여에 동의한 해당기 관에 직접 방문하여 유아교육기관 원장과 담임교사에게 연구 의 방법과 주의사항 등을 설명하였다. 작성된 질문지는 담임 교사를 통해 각 가정으로 전달하여 어머니들이 응답하도록 하 였으며 유아를 통해 다시 담임교사가 회수하도록 하였다. 배 부된 400 부의 질문지 중 345 부가 회수되었으며(약 $86 \%$ 의 회 수율), 이 중 불성실하게 답변한 질문지 19 부를 제외한 326부 를 최종분석에 사용하였다. 수집된 자료는 SPSS 22.0 (IBM Co., Armonk, NY)을 사용하여 분석하였다. 우선 연구대상의 사회인구학적 특성을 살펴보기 위해 빈도와 백분율을 산출하 였고, 조사도구의 신뢰도를 알아보기 위해 Cronbach's $\alpha$ 를 산 출하였다. 또한 기초분석으로 각 연구변인의 성차와 연령차가 있는지 알아보기 위해 각각 $t$ 검증과 일원변량분석을 실시하 였으며 연구변인들의 평균과 표준편차를 산출하였다. 이와 함 께 유아의 기질 및 어머니의 부모역할만족도와 양육스트레스 간의 관계를 파악하기 위해서 Pearson의 상관분석을 실시하였 다. 그리고 유아의 기질이 어머니의 양육스트레스에 미치는 영향과 어머니의 부모역할만족도가 양육스트레스에 미치는
영향, 유아의 기질이 어머니의 부모역할만족도에 미치는 영향 은 각각 회귀분석을 실시하였다. 또한 유아의 기질과 어머니 의 양육스트레스 간의 관계에서 어머니의 부모역할만족도의 매개효과에 대해서는 중다회귀분석을 실시하였다. 매개효과 가 유의한지 확인하기 위해 Sobel test를 이용하여 검증하였다. 회귀분석을 실시하기 전 회귀식 기본과정인 다중공선성 위반 여부를 검토하기 위해 $\operatorname{VIF}$ (분산팽창계수)와 Tolerance(공차한 계)를 확인한 결과, 각각 10 이하(1.03 2.20)와 0.1 이상(0.46 0.97)으로 나타나 다중공선성 문제가 없는 것으로 판단되었 다(Berry \& Feldman, 1985).

\section{연구결과}

\section{기초분석}

유아의 성별과 연령에 따라 유아의 기질 및 어머니의 부모역할 만족도와 양육스트레스에서의 차이가 있는지 살펴보기 위해 $t$ 검증과 일원변량분석을 실시하였다. 그 결과, 유아의 성과 연 령에 따른 차이가 발견되지 않았다. 다음으로 유아의 기질 및 어머니의 부모역할만족도와 양육스트레스 간의 상관관계를 알아보기 위해 Pearson의 적률상관계수를 산출하였다. 첫째, 유 아의 기질과 어머니의 양육스트레스 간의 상관관계를 살펴본 결과 적응적 기질, 규칙적 기질이 부모의 고통과 부적으로 유 의한 상관을 보였다 $(r=-.18, p<.01 ; r=-.11, p<.05)$. 또한 적응 적 기질과 규칙적 기질이 부모-자녀간 역기능적 상호작용과 부 적으로 유의한 상관을 보였으나 $(r=-.43 ; p<.001 ; r=-.19, p<$ $.01)$ 활발한 기질은 정적으로 유의한 상관을 보였다 $(r=.13, p$ $<.05)$. 적응적 기질, 규칙적 기질은 자녀의 특성과 부적으로 유 의한 상관을 보였으나 $(r=-.33, p<.001 ; r=-.16, p<.01)$ 활발한 기질은 정적으로 유의한 상관을 보였다 $(r=.17, p<.01)$.

둘째, 부모역할만족도와 어머니의 양육스트레스 간의 상 관관계를 살펴보면 일반적 만족도, 부모자녀관계, 배우자지 지, 부모역할갈등, 자녀의 지지는 부모의 고통과 부적으로 유 의한 상관을 보였다 $(r=-.29, p<.001 ; \mathrm{r}=-.29, p<.001 ; r=-.30$, $p<.001 ; r=-.53, p<.001 ; r=-.18, p<.01)$. 또한 일반적 만족 도, 부모자녀관계, 배우자 지지, 부모역할갈등, 자녀의 지지와 부적으로 유의한 상관을 보였다 $(r=-.46, p<.001 ; r=-.59, p<$ $.001 ; r=-.34, p<.001 ; r=-.61, p<.001 ; r=-.42, p<.001)$. 그리 고 일반적 만족도, 부모자녀관계, 배우자 지지, 부모역할갈등, 자녀의 지지는 자녀의 특성과 부적으로 유의한 상관을 보였다 
Table 1

Correlations Among Children's Temperament, Parenting Stress and Parental Satisfaction

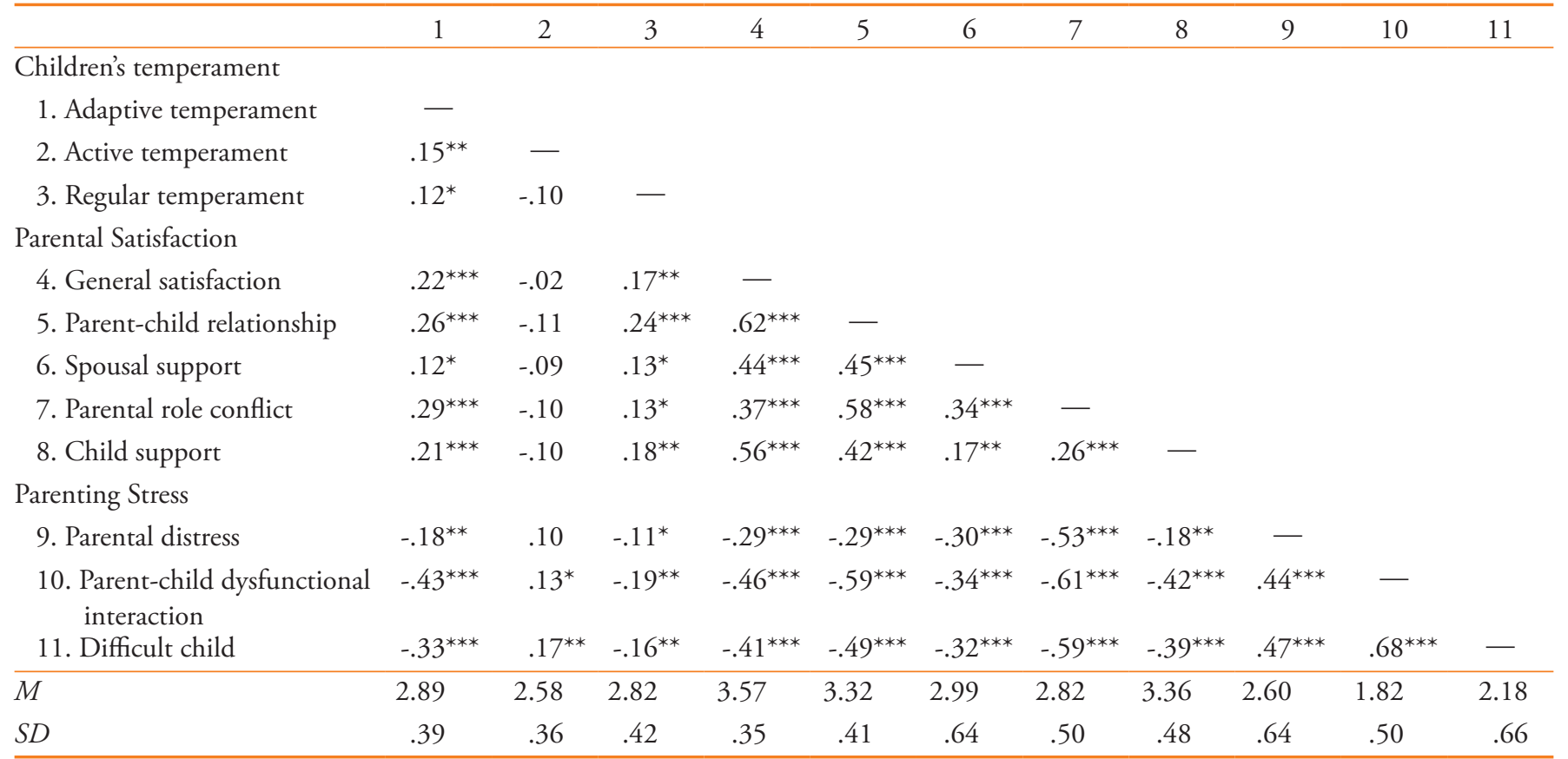

Note. $N=326$.

${ }^{*} p<.05 .{ }^{* *} p<.01 .{ }^{* * *} p<.001$.

$(r=-.41, p<.001 ; r=-.49, p<.001 ; r=-.32, p<.001 ; r=-.59, p$ $<.001 ; r=-.39, p<.001)$.

셋째, 유아의 기질과 부모역할만족도 간의 상관관계를 살 펴보면 적응적 기질, 규칙적 기질은 일반적 만족도와 정적으로 유의한 상관을 보였다 $(r=.22, p<.001 ; r=.17, p<.01)$. 또한 적 응적 기질, 규칙적 기질은 부모자녀관계와 정적으로 유의한 상 관을 보였다 $(r=.26, p<.001 ; r=.24, p<.001)$. 적응적 기질, 규 칙적 기질은 배우자 지지와 정적으로 유의한 상관을 보였다 $(r$ $=.12, p<.05 ; r=.13, p<.05)$. 적응적 기질, 규칙적 기질은 부모 역할갈등과 정적으로 유의한 상관을 보였다 $(r=.29, p<.001 ; r$ $=.13, p<.05)$. 적응적 기질, 규칙적 기질은 자녀의 지지와 정적 으로 유의한 상관을 보였다 $(r=.21, p<.001 ; r=.18, p<.01)$.

\section{유아의 기질이 어머니 양육스트레스에 미치는 영향}

유아의 기질이 어머니의 양육스트레스에 미치는 영향을 살펴 보기 위해 중다회귀분석을 실시하였다. 즉, 어머니의 양육스 트레스의 각 요인들을 종속변인으로 하고, 유아의 기질의 각 요인들을 독립변인으로 투입하였다. 그 결과, 유아의 적응적 기질, 활발한 기질이 부모의 고통으로 인한 양육스트레스에 유
의한 영향을 미쳤으며 $(\beta=-.19, p<.01 ; \beta=.12, p<.05)$ 그 설명 력은 $6 \%$ 였다. 유아의 적응적 기질, 활발한 기질, 규칙적 기질이 부모-자녀간 역기능적 상호작용으로 인한 양육스트레스에 유 의한 영향을 미쳤으며 $(\beta=-.44, p<.001 ; \beta=.19, p<.001 ; \beta=-.11$, $p<.05)$ 그 설명력은 $23 \%$ 였다. 또한 유아의 적응적 기질, 활발 한 기질이 자녀의 특성으로 인한 양육스트레스에 유의한 영 향을 미쳤으며 $(\beta=-.35, p<.001 ; \beta=.21, p<.001)$ 그 설명력은 $17 \%$ 였다. 즉, 유아의 기질의 적응성이 낮고 활동성이 높을수 록 부모의 고통으로 인한 양육스트레스가 높았으며, 유아의 기 질의 적응성이 낮고 활동성이 높으며 규칙성이 낮을수록 부모자녀간 역기능적 상호작용으로 인한 양육스트레스가 높았다. 그리고 유아의 기질의 적응성이 낮고 활동성이 높을수록 자녀 의 특성으로 인한 양육스트레스가 높았다.

\section{어머니의 부모역할만족도가 양육스트레스에 미치는 영향}

어머니의 부모역할만족도가 양육스트레스에 미치는 영향을 살펴보기 위해 중다회귀분석을 실시하였다. 즉, 어머니의 양 육스트레스의 각 요인들을 종속변인으로 하고, 부모역할만족 도의 각 요인들을 투입하였다. 그 결과, 일반적 만족도, 배우자 
Table 2

Children's Temperament Regression Analysis on Parenting Stress of Mothers

\begin{tabular}{lccc}
\hline & & Parenting stress & \\
\cline { 2 - 4 } & Parental distress & Parent-child dysfunctional interaction & Difficult child \\
\hline Children's temperament & & & $-.35^{* * *}$ \\
Adaptive temperament & $-.19^{* *}$ & $-.44^{* * *}$ & $.21^{* * *}$ \\
Active temperament & $.12^{*}$ & $.19^{* * *}$ & -.10 \\
Regular temperament & -.08 & $-.11^{*}$ & .17 \\
\hline$R^{2}$ & .06 & .23 & $21.53^{* * *}(3,322)$ \\
$F(d f)$ & $6.24^{* * *}(3,322)$ & $32.65^{* * *}(3,322)$ & \\
\hline
\end{tabular}

Note. $N=326$.

${ }^{*} p<.05 .{ }^{* *} p<.01 .{ }^{* * *} p<.001$.

Table 3

Parental Satisfaction Regression Analysis on Parenting Stress of Mothers

Parenting stress

Parental distress

Parent-child dysfunctional interaction

Difficult child

Parenting satisfaction

\begin{tabular}{llll} 
General satisfaction & $-.13^{*}$ & -.05 & -.06 \\
Parent-child relationship & .07 & $-.23^{* * *}$ & -.09 \\
Spousal support & $-.12^{*}$ & -.05 & -.07 \\
Parental role conflict & $-.53^{* * *}$ & $-.40^{* * *}$ & $-.44^{* * *}$ \\
Child support & -.02 & $-.19^{* * *}$ & $-.20^{* * *}$ \\
\hline$R^{2}$ & .31 & .50 & .42 \\
$F(d f)$ & $29.29^{* * *}(3,322)$ & $63.03^{* * *}(3,322)$ & $46.90^{* * *}(3,322)$ \\
\hline
\end{tabular}

Note. $N=326$.

${ }^{*} p<.05 .{ }^{* * *} p<.001$.

지지, 부모역할갈등이 부모의 고통으로 인한 양육스트레스에 유의한 영향을 미쳤으며 $(\beta=-.13, p<.05 ; \beta=-.12, p<.05 ; \beta=$ $-.53, p<.001)$ 그 설명력은 $31 \%$ 였다. 부모자녀관계, 부모역할 갈등, 자녀의 지지가 부모-자녀간 역기능적 상호작용으로 인 한 양육스트레스에 유의한 영향을 미쳤으며 $(\beta=-.23, p<.001$; $\beta=-.40, p<.001 ; \beta=-.19, p<.001)$ 그 설명력은 $50 \%$ 였다. 또 한 부모역할갈등, 자녀의 지지가 자녀의 특성으로 인한 양육 스트레스에 유의한 영향을 미쳤으며 $(\beta=-.44, p<.001 ; \beta=-.20$, $p<.001)$ 그 설명력은 $42 \%$ 였다. 즉, 일반적인 부모역할에 대 한 만족도와 배우자 지지, 부모역할갈등에 대한 만족도가 높 을수록 부모의 고통으로 인한 양육스트레스가 낮았다. 그리고 부모자녀관계와 부모역할갈등, 자녀의 지지에 대한 만족도가 높을수록 부모-자녀간 역기능적 상호작용으로 인한 양육스트 레스가 낮았다. 또한 부모역할갈등에 대한 만족도가 높고 자 녀의 지지에 대한 만족이 높을수록 자녀의 특성으로 인한 양 육스트레스가 낮았다.

\section{유아의 기질이 어머니의 부모역할만족도에 미치 는 영향}

유아의 기질이 어머니의 양육스트레스에 미치는 영향을 살펴 보기 위해 중다회귀분석을 실시하였다. 즉, 어머니의 부모역 할만족도의 각 요인들을 종속변인으로 하고, 유아의 기질의 각 요인들을 독립변인으로 투입하였다. 그 결과, 유아의 적응 적 기질, 규칙적 기질이 일반적 만족도에 유의한 영향을 미쳤 으며 $(\beta=.21, p<.001 ; \beta=.14, p<.05)$ 그 설명력은 $7 \%$ 였다. 유 아의 적응적 기질, 활발한 기질, 규칙적 기질이 부모자녀관계 에 유의한 영향을 미쳤으며 $(\beta=.26, p<.001 ; \beta=-.13, p<.05$; $\beta=.20, p<.001)$ 그 설명력은 $13 \%$ 였다. 유아의 적응적 기질 이 배우자 지지에 유의한 영향을 미쳤으며 $(\beta=.12, p<.05)$, 유 아의 적응적 기질, 활발한 기질이 부모역할갈등에 의한 영향 을 미쳤으며 $(\beta=.30, p<.001 ; \beta=-.14, p<.05)$ 그 설명력은 각 각 $4 \%, 10 \%$ 였다. 유아의 적응적 기질, 활발한 기질, 규칙적 기 
Table 4

Children's Temperament Regression Analysis on Parental Satisfaction

\begin{tabular}{|c|c|c|c|c|c|}
\hline & \multicolumn{5}{|c|}{ Parenting satisfaction } \\
\hline & $\begin{array}{c}\text { General } \\
\text { satisfaction }\end{array}$ & $\begin{array}{l}\text { Parent-child } \\
\text { relationship }\end{array}$ & $\begin{array}{l}\text { Spousal } \\
\text { support }\end{array}$ & $\begin{array}{c}\text { Parental } \\
\text { role conflict }\end{array}$ & $\begin{array}{l}\text { Child } \\
\text { support }\end{array}$ \\
\hline \multicolumn{6}{|l|}{ Children's temperament } \\
\hline Adaptive temperament & $.21^{* * *}$ & $.26^{* * *}$ & $.12^{*}$ & $.30^{* * *}$ & $.21^{* * *}$ \\
\hline Active temperament & -.04 & $-.13^{*}$ & -.10 & $-.14^{*}$ & $-.12^{*}$ \\
\hline Regular temperament & $.14^{*}$ & $.20^{* * *}$ & .11 & .08 & $.14^{*}$ \\
\hline$R^{2}$ & .07 & .13 & .04 & .10 & .08 \\
\hline$F(d f)$ & $\begin{array}{l}8.09^{* * *} \\
(3,322)\end{array}$ & $\begin{array}{l}15.77^{* * *} \\
(3,322)\end{array}$ & $\begin{array}{c}4.22^{* * *} \\
(3,322)\end{array}$ & $\begin{array}{l}13.01^{\text {*** }} \\
(3,322)\end{array}$ & $\begin{array}{c}9.52^{* * *} \\
(3,322)\end{array}$ \\
\hline
\end{tabular}

Note. $N=326$.

${ }^{*} p<.05 .{ }^{* * *} \mathrm{p}<.001$.

질이 자녀의 지지에 유의한 영향을 미쳤으며 $(\beta=.21, p<.001$; $\beta=-.12, p<.05 ; \beta=.14, p<.05)$ 그 설명력은 $8 \%$ 였다. 즉, 유아 의 기질의 적응성과 규칙성이 높을수록 부모역할에 대한 일반 적 만족도가 높았으며 유아의 기질의 적응성과 규칙성이 높고 활동성이 낮을수록 부모자녀관계에 대한 만족도가 높았다. 또 한, 유아의 기질의 적응성이 높을수록 배우자 지지에 대한 만 족도가 높으며 유아의 기질의 적응성이 높고 활동성이 낮을수 록 부모역할갈등에 대한 만족도가 높았다. 그리고 유아의 기 질의 적응성과 규칙성이 높고 활동성이 낮을수록 자녀의 지지 에 대한 만족도가 높았다.

\section{유아의 기질과 어머니의 양육스트레스 간의 관계에서 부모역할만족도의 매개효과}

아동의 기질과 어머니의 양육스트레스 간의 관계에서 부모역 할만족도의 매개효과를 살펴보기 위하여 Baron과 Kenny (1986) 가 제안한 세 가지 단계의 접근 모델에 근거하여 회귀분석을 실 시하였다. 먼저 독립변인이 매개변인에 미치는 영향력을 살펴 보았고, 그 다음으로는 독립변인이 종속변인에 미치는 영향력 을 살펴보았으며, 마지막으로 독립변인과 매개변인이 동시에 투입하였을 때 종속변인에 미치는 영향력을 살펴보았다.

유아의 기질(적응적 기질/활발한 기질)과 어머 니의 양육스트레스(부모의 고통) 간의 관계에서 부모역할만족도(일반적 만족도/부모자녀관계/ 부모역할갈등)의 매개효과

유아의 적응적 기질과 부모의 고통 간의 관계에서 일반적 만족
도, 부모자녀관계, 부모역할갈등의 매개효과에 대해 살펴보았 다. 첫 번째 단계에서 유아의 적응적 기질은 어머니의 일반적 만족도, 부모자녀관계, 부모역할갈등에 유의한 영향을 미쳤고 $(\beta=.21, p<.001 ; \beta=.26, p<.001 ; \beta=.30, p<.001)$, 두 번째 단 계에서 유아의 적응적 기질은 부모의 고통에 유의한 영향을 미 쳤다 $(\beta=-.19, p<.01)$. 세 번째 단계에서 유아의 적응적 기질과 어머니의 일반적 만족도, 부모자녀관계, 부모역할갈등을 각각 동시에 투입하였을 때, 일반적 만족도, 부모자녀관계는 부모의 고통에 유의한 영향을 미쳤으며 $(\beta=-.25, p<.001 ; \beta=-.24, p<$ .001), 유아의 적응적 기질이 부모의 고통에 미치는 영향은 유 의도가 감소하였다 $(\beta=-.19, p<.01 \rightarrow \beta=-.14, p<.05 ; \beta=-.19$, $p<.01 \rightarrow \beta=-.13, p<.05)$. 또한 부모역할갈등은 부모의 고통 에 유의한 영향을 미쳤으며 $(\beta=-.51, p<.001)$, 유아의 적응적 기질은 부모의 고통에 더 이상 영향을 미치지 않았다 $(\beta=.30, p$ $<.001 \rightarrow n s)$. 즉 일반적 만족도와 부모자녀관계는 유아의 적응 적 기질과 부모의 고통 간의 관계에서 각각 부분 매개가 나타 났고, 부모역할갈등은 유아의 적응적 기질과 부모의 고통 간의 관계에서 완전 매개가 나타났다. 이에 대한 매개효과가 유의한 지 알아보기 위해 Sobel test를 실시한 결과 각각 $z=-2.93(p<$ $.01), z=-3.04$ ( $p<.01), z=-4.70$ ( $p<.001)$ 로 유의하였다.

다음으로, 유아의 활발한 기질과 부모의 고통 간의 관계에 서 부모자녀관계, 부모역할갈등의 매개효과에 대해 살펴보았 다. 첫 번째 단계에서 유아의 활발한 기질은 어머니의 부모자 녀관계, 부모역할갈등에 유의한 영향을 미쳤으며 $(\beta=-.13, p$ $<.05 ; \beta=-.14, p<.05)$, 두 번째 단계에서도 유아의 활발한 기 질은 부모의 고통에 유의한 영향을 미쳤다 $(\beta=.12, p<.05)$. 세 번째 단계에서 유아의 활발한 기질과 어머니의 부모자녀관계, 부모역할갈등을 각각 동시에 투입하였을 때, 부모자녀관계, 
Table 5

Regression Analysis on Mediating Effects of Parental Satisfaction on Relationship Between Children's Temperament and Parenting Stress of Mothers (Parental Distress)

\begin{tabular}{|c|c|c|c|c|c|c|}
\hline & & Variables & $B$ & $\beta$ & $R^{2}$ & $F$ \\
\hline \multicolumn{7}{|l|}{ Adaptive temperament } \\
\hline 1. Adaptive temperament & $\rightarrow$ & General satisfaction & .19 & $.21^{* * *}$ & .07 & $8.09^{* * *}$ \\
\hline 2. Adaptive temperament & $\rightarrow$ & Parental distress & -.31 & $-.19^{* * *}$ & .06 & $6.24^{* * *}$ \\
\hline 3. Adaptive temperament & $\rightarrow$ & \multirow{2}{*}{ Parental distress } & -.23 & $-.14^{*}$ & .11 & $10.23^{* * *}$ \\
\hline General satisfaction & $\rightarrow$ & & -.46 & $-.25^{* * *}$ & & $10.23^{* * *}$ \\
\hline 1. Adaptive temperament & $\rightarrow$ & Parent-child relationship & .27 & $.26^{* * *}$ & .13 & $15.77^{* * *}$ \\
\hline 2. Adaptive temperament & $\rightarrow$ & Parental distress & -.31 & $-.19^{* *}$ & .06 & $6.24^{* * *}$ \\
\hline 3. Adaptive temperament & $\rightarrow$ & \multirow{2}{*}{ Parental distress } & -.21 & $-.13^{*}$ & .10 & $9.29^{* * *}$ \\
\hline Parent-child relationship & $\rightarrow$ & & -.37 & $-.24^{* * *}$ & & $9.29^{* * *}$ \\
\hline 1. Adaptive temperament & $\rightarrow$ & Parental role conflict & .38 & $.30^{* * *}$ & .11 & $13.01^{* * *}$ \\
\hline 2. Adaptive temperament & $\rightarrow$ & Parental distress & -.31 & $-.19^{* *}$ & .06 & $6.24^{* * *}$ \\
\hline 3. Adaptive temperament & $\rightarrow$ & \multirow{2}{*}{ Parental distress } & -.06 & -.04 & .29 & $32.57^{* * *}$ \\
\hline Parental role conflict & $\rightarrow$ & & -.66 & $-.51^{* * *}$ & & $32.57^{* * *}$ \\
\hline \multicolumn{7}{|l|}{ Active temperament } \\
\hline 1. Active temperament & $\rightarrow$ & Parent-child relationship & -.14 & $-.13^{*}$ & .31 & $62.66^{* * *}$ \\
\hline 2. Active temperament & $\rightarrow$ & Parental distress & .22 & $.12^{*}$ & .06 & $6.24^{* * *}$ \\
\hline 3. Active temperament & $\rightarrow$ & \multirow{2}{*}{ Parental distress } & .16 & .09 & .10 & $9.29^{* * *}$ \\
\hline Parent-child relationship & $\rightarrow$ & & -.37 & $-.24^{* * *}$ & & $9.29^{* * *}$ \\
\hline 1. Active temperament & $\rightarrow$ & Parental role conflict & -.18 & $-.14^{*}$ & .11 & $13.01^{* * *}$ \\
\hline 2. Active temperament & $\rightarrow$ & Parental distress & .22 & $.12^{*}$ & .06 & $6.24^{* * *}$ \\
\hline 3. Active temperament & $\rightarrow$ & \multirow{2}{*}{ Parental distress } & .09 & .05 & .29 & $32.57^{* * *}$ \\
\hline Parental role conflict & $\rightarrow$ & & -.66 & $-.51^{* * *}$ & & $32.57^{* * *}$ \\
\hline
\end{tabular}

Note. $N=326$.

${ }^{*} p<.05 .{ }^{* *} p<.01 .{ }^{* * *} p<.001$.

부모역할갈등 만이 각각 부모의 고통에 유의한 영향을 미쳤으 며 $(\beta=-.24, p<.001 ; \beta=-.19, p<.01 \rightarrow \beta=-.13, p<.05)$, 유아 의 활발한 기질은 부모의 고통에 더 이상 유의한 영향을 미치 지 않았다 $(\beta=-.13, p<.05 ; \beta=-.14, p<.05 \rightarrow n s)$. 즉, 부모자 녀관계와 부모역할갈등은 유아의 활발한 기질과 부모의 고통 간의 관계에서 각각 완전 매개가 나타났다. 이에 대한 매개효 과가 유의한지 알아보기 위해 Sobel test를 실시한 결과 각각 $z$ $=2.03(p<.05), z=2.61(p<.01)$ 로 유의하였다.

유아의 기질(활발한 기질/규칙적 기질)과 양육 스트레스(부모-자녀간 역기능적 상호작용) 간 의 관계에서 부모역할만족도(부모자녀관계/부 모역할갈등)의 매개효과

유아의 활발한 기질과 부모-자녀간 역기능적 상호작용 간의
관계에서 부모자녀관계, 부모역할갈등의 매개효과에 대해 살 펴보았다. 먼저 부모자녀관계의 매개효과에 대해 살펴본 결 과, 첫 번째 단계에서 유아의 활발한 기질은 부모자녀관계, 부 모역할갈등에 유의한 영향을 미쳤으며 $(\beta=-.13, p<.05 ; \beta=$ $-.14, p<.05)$, 두 번째 단계에서도 유아의 활발한 기질은 부모자녀 간 역기능적 상호작용에 유의한 영향을 미쳤다 $(\beta=.19$, $p<.001)$. 세 번째 단계에서 유아의 활발한 기질과 부모자녀관 계, 부모역할갈등을 동시에 투입하였을 때 부모자녀관계가 부 모-자녀간 역기능적 상호작용에 미치는 영향은 유의하지만( $\beta$ $=-.49, p<.001 ; \beta=-.51, p<.001)$, 유아의 활발한 기질이 부모자녀간 역기능적 상호작용에 미치는 영향은 유의도가 낮아졌 다 $(\beta=.19, p<.001 \rightarrow \beta=.12, p<.01)$. 즉, 부모자녀관계, 부모 역할갈등은 유아의 활발한 기질과 부모-자녀간 역기능적 상 호작용의 관계에서 각각 부분 매개가 나타났다. 이에 대한 매 개효과가 유의한지 알아보기 위해 Sobel test를 실시한 결과 각 
Table 6

Regression Analysis on Mediating Effects of Parental Satisfaction on Relationship Between Children's Temperament and Parenting Stress of Mothers (Parent-Child Dysfunctional Interaction)

\begin{tabular}{lllllll}
\hline & & Variables & $B$ & $\beta$ & $R^{2}$ & $F$ \\
\hline Active temperament & & & & & & \\
1. Active temperament & $\rightarrow$ & Parent-child relationship & -.14 & $-.13^{*}$ & .13 & $15.77^{* * *}$ \\
2. Active temperament & $\rightarrow$ & Parent-child dysfunctional interaction & .25 & $.19^{* * *}$ & .23 & $32.65^{* * *}$ \\
3. Active temperament & $\rightarrow$ & Parent-child dysfunctional interaction & .17 & $.12^{* *}$ & .44 & $63.99^{* * *}$ \\
$\quad$ Parent-child relationship & $\rightarrow$ & & -.59 & $-.49^{* * *}$ & & \\
\hline 1. Active temperament & $\rightarrow$ & Parental role conflict & -.19 & $-.14^{*}$ & .11 & $13.01^{* * *}$ \\
2. Active temperament & $\rightarrow$ & Parent-child dysfunctional interaction & .25 & $.19^{* * *}$ & .23 & $32.65^{* * *}$ \\
3. Active temperament & $\rightarrow$ & Parent-child dysfunctional interaction & .16 & $.12^{* *}$ & .46 & $69.53^{* * *}$ \\
$\quad$ Parental role conflict & $\rightarrow$ & & -.51 & $-.51^{* * *}$ & & \\
\hline Regular temperament & & & & & & \\
1. Regular temperament & $\rightarrow$ & Parent-child relationship & .19 & $.20^{* * *}$ & .13 & $15.77^{* * *}$ \\
2. Regular temperament & $\rightarrow$ & Parent-child dysfunctional interaction & -.13 & $-.11^{*}$ & .23 & $32.65^{* * *}$ \\
3. Regular temperament & $\rightarrow$ & Parent-child dysfunctional interaction & -.02 & -.02 & .44 & $63.99^{* * *}$ \\
\multicolumn{1}{l}{ Parent-child relationship } & $\rightarrow$ & & -.59 & $-.49^{* * *}$ & & \\
\hline
\end{tabular}

Note. $N=326$.

${ }^{*} p<.05 .{ }^{* *} p<.01 .{ }^{* * *} p<.001$.

각 $z=2.29(p<.05), z=2.65(p<.01)$ 로 유의하였다.

다음으로 유아의 규칙적 기질과 부모-자녀간 역기능적 상 호작용 간의 관계에서 부모자녀관계의 매개효과에 대해 살펴 보았다. 첫 번째 단계에서 유아의 규칙적 기질은 부모자녀관 계에 유의한 영향을 미쳤으며 $(\beta=.20, p<.001)$, 두 번째 단계 에서도 유아의 규칙적 기질은 부모-자녀간 역기능적 상호작 용에 유의한 영향을 미쳤다 $(\beta=-.11, p<.05)$. 세 번째 단계에 서 유아의 규칙적 기질과 부모자녀관계를 동시에 투입하였을 때, 부모자녀관계 만이 부모-자녀간 역기능적 상호작용에 유 의한 영향을 미쳤으며 $(\beta=-.49, p<.001)$, 유아의 규칙적 기질 은 부모-자녀간 역기능적 상호작용에 더 이상 유의한 영향을 미치지 않았다 $(\beta=.20, p<.001 \rightarrow n . s)$. 즉, 부모자녀관계에 대 한 만족도는 유아의 규칙적 기질과 부모-자녀간 역기능적 상 호작용 간의 관계에서 완전 매개가 나타났다. 부모자녀관계의 매개효과가 유의한지 알아보기 위해 Sobel test를 실시한 결과 $z=-3.62(p<.001)$ 로 유의하였다.

유아의 기질(활발한 기질)과 양육스트레스(자녀 의 특성) 간의 관계에서 부모역할만족도(부모자 녀관계/부모역할갈등)의 매개효과

유아의 활발한 기질과 자녀의 특성으로 인한 양육스트레스 간
의 관계에서 부모자녀관계, 부모역할갈등의 매개효과에 대해 살펴보았다. 먼저 부모자녀관계의 매개효과에 대해 살펴본 결 과, 첫 번째 단계에서 유아의 활발한 기질은 부모자녀관계, 부 모역할갈등에 유의한 영향을 미쳤으며 $(\beta=-.13, p<.05 ; \beta=-.14$, $p<.05)$, 두 번째 단계에서도 유아의 활발한 기질은 자녀의 특 성으로 인한 양육스트레스에 유의한 영향을 미쳤다 $(\beta=.21, p$ <.001). 세 번째 단계에서 유아의 활발한 기질과 부모자녀관계, 부모역할갈등을 각각 동시에 투입하였을 때 부모자녀관계, 부 모역할갈등이 자녀의 특성으로 인한 양육스트레스에 미치는 영향은 유의하지만 $(\beta=-.40, p<.001 ; \beta=-.51, p<.001)$, 유아의 활발한 기질이 자녀의 특성으로 인한 양육스트레스에 미치는 영향은 유의도가 낮아졌다 $(\beta=.21, p<.001 \rightarrow \beta=.16, p<.01$; $\beta=.21, p<.001 \rightarrow \beta=.14, p<.01)$. 즉, 부모자녀관계와 부모역 할갈등은 유아의 활발한 기질과 자녀의 특성으로 인한 양육스 트레스 간의 관계에서 각각 부분 매개가 나타났다. 이에 대한 매개효과가 유의한지 알아보기 위해 Sobel test를 실시한 결과 각각 $z=2.24(p<.05), z=2.64$ ( $p<.01)$ 로 유의하였다.

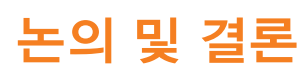

본 연구에서는 3세 5세 유아들을 대상으로 유아의 기질 및 
Table 7

Regression Analysis on Mediating Effects of Parental Satisfaction on Relationship Between Children's Temperament and Parenting Stress of Mothers (Difficult Child)

\begin{tabular}{lllllll}
\hline & & Variables & $B$ & $\beta$ & $R^{2}$ & $F$ \\
\hline Active temperament & & & & & & \\
1. Active temperament & $\rightarrow$ & Parent-child relationship & -.14 & $-.13^{*}$ & .13 & $15.77^{* * *}$ \\
2. Active temperament & $\rightarrow$ & Difficult child & .38 & $.21^{* * *}$ & .17 & $21.53^{* * *}$ \\
3. Active temperament & $\rightarrow$ & Difficult child & .29 & $.16^{* *}$ & .31 & $35.90^{* * *}$ \\
$\quad$ Parent-child relationship & $\rightarrow$ & & -.64 & $-.40^{* * *}$ & & \\
\hline 1. Active temperament & $\rightarrow$ & Parental role conflict & -.19 & $-.14^{*}$ & .11 & $13.01^{* * *}$ \\
2. Active temperament & $\rightarrow$ & Difficult child & .38 & $.21^{* * *}$ & .17 & $21.53^{* * *}$ \\
3. Active temperament & $\rightarrow$ & Difficult child & .26 & $.14^{* *}$ & .40 & $52.63^{* * *}$ \\
\multicolumn{1}{l}{ Parental role conflict } & $\rightarrow$ & & -.67 & $-.51^{* * *}$ & & \\
\hline
\end{tabular}

Note. $N=326$.

${ }^{*} p<.05 .{ }^{* *} p<.01 .{ }^{* * *} p<.001$.

어머니의 부모역할만족도가 양육스트레스에 미치는 영향을 살펴보고, 어머니의 부모역할만족도가 유아의 기질과 어머니 의 양육스트레스 간의 관계에서 매개효과를 나타내는지 조사 하였다. 본 연구의 결과를 중심으로 논의하면 다음과 같다.

유아의 기질이 어머니의 양육스트레스에 미치는 영향을 살 펴본 결과, 유아의 기질의 적응성이 낮고 활동성이 높을수록 부모의 고통으로 인한 양육스트레스가 높았으며, 유아의 기질 의 적응성이 낮고 활동성이 높으며 규칙성이 낮을수록 부모자녀관계 영역에 대한 양육스트레스가 높았다. 또한 유아의 기질의 적응성이 낮고 활동성이 높을수록 아동 영역에 대한 양육스트레스가 높았다. 이와 같은 결과는 아동의 기질이 까 다로울수록 어머니의 양육스트레스가 높았다는 연구결과(Y. Y. Jo, 2014; Nam, 2003; Shin, 2011)와 새로운 상황에 적응을 잘 하지 못하고 활동성이 높고 규칙성이 낮을수록 어머니의 양 육스트레스가 높았다는 연구결과(Y. S. Jo \& Jung, 2000), 아동 의 기질이 활동적일수록 어머니의 양육스트레스가 높았다는 연구결과(Y.-J. Lee, 2014; S. Y. Park et al., 1996)와 일치한다. 즉, 유아가 새로운 환경에 보다 적응적이고 생활 전반에 규칙적이 며 신체적 움직임의 활동성이 낮을수록 어머니는 양육스트레 스를 덜 받는다고 볼 수 있다.

이러한 결과는 본 연구 대상이 유아교육기관에 다니는 3 세 5세의 유아가 대부분으로 유아가 새롭거나 변화된 상황에 잘 적응하지 못하면 어머니가 스트레스를 받는다고 볼 수 있 다. 더불어 유아가 신체적 움직임과 같은 활동성이 높은 기질 을 보이는 경우 부모가 자녀를 위험으로부터 보호해야할 것이 많으며 자녀와 함께 놀이를 해주거나 돌봐야할 것이 많아 어 머니의 양육스트레스가 높게 나타났다고 이해해 볼 수 있다.
또한 유아교육기관에 다니는 유아를 자녀로 둔 어머니들에게 자녀의 규칙성은 교육기관의 적응과도 관련이 깊어 자녀의 수 면, 식사, 일상습관 규칙성 정도는 어머니의 양육스트레스에 영향을 준 것으로 해석할 수 있다. 이와 같은 결과는 어머니의 양육스트레스에 있어 자녀의 기질이 중요함을 시사하고 있다. 따라서 어머니의 양육스트레스를 완화시키기 위해 무엇보다 자녀의 기질에 대한 이해가 우선 되어야 하며 자녀의 기질을 수용하려는 노력이 필요할 것이다. 또한, 유아교육 기관 내에 자녀의 기질을 측정하고 기질특성, 기질에 따른 놀이법에 대 한 부모교육 프로그램을 제공하는 것이 바람직할 것이다. 나 아가 부모상담에서 자녀의 기질 파악 및 올바른 양육법의 지 도가 이루어지는 것도 유익할 것이다.

어머니의 부모역할만족도가 양육스트레스에 어떠한 영향 을 미치는지 살펴본 결과를 양육스트레스의 하위요인별로 보 면 다음과 같다. 첫째, 어머니의 부모역할에 대한 일반적 만족 도가 높고 배우자의 지지에 대한 만족도와 부모역할갈등이 적 어 이에 대한 만족도가 높을수록 부모 영역에 대한 양육스트 레스가 낮았다. 둘째, 부모자녀관계에 대한 만족도가 높고 부 모역할갈등이 적어 이에 대한 만족도가 높으며 자녀의 지지에 대한 만족도가 높을수록 부모-자녀관계 영역에 대한 양육스 트레스가 낮았다. 셋째, 부모역할갈등이 적어 이에 대한 만족 도가 높고 자녀의 지지에 대한 만족도가 높을수록 아동 영역 에 대한 양육스트레스가 낮았다. 이와 같은 결과는 어머니의 부모역할만족도가 높으면 양육스트레스가 낮았다는 연구결 과들(A.-M. Noh, 2008; J. Y. Noh \& Hwang, 2012; Song \& Song, 2007)과 일치한다. 즉, 어머니가 부모역할에 대한 만족감을 느 낄수록 자녀의 양육과정에서 경험할 수 있는 스트레스를 감소 
시키며 어머니 본인 또한 양육스트레스를 덜 지각하는 것으로 도 해석해볼 수 있다.

이러한 결과는 어머니의 양육스트레스에 있어 부모역할만 족도가 중요함을 나타내는 것으로, 어머니에게 부모됨이나 부 모역할에 관한 이해가 선행되어야 함을 보여준다. 즉, 부모가 되기 이전에 부모 역할에 대한 적절한 기대가 필요하며, 이러 한 내용을 다룬 예비부모교육이 학교나 사회단체 등을 통해 실 시되는 것이 효과적일 것이다. 또한, 유아교육기관에서 정기적 으로 실시하는 부모교육에 부모가 자신의 부모역할에 대한 만 족감을 높일 수 있도록 어머니 자신의 이해 및 자녀 이해를 내 용으로 한 교육 및 상담의 체계적 실시도 바람직할 것이다.

유아의 기질이 어머니의 부모역할만족도에 미치는 영향을 살펴본 결과, 유아의 기질의 적응성과 규칙성이 높을수록 부 모역할에 대한 일반적 만족도가 높았으며 유아의 기질의 적응 성과 규칙성이 높고 활동성이 낮을수록 부모자녀관계에 대한 만족도가 높았다. 또한 유아의 기질의 적응성이 높을수록 배 우자 지지에 대한 만족도가 높으며 유아의 기질의 적응성이 높고 활동성이 낮을수록 부모역할갈등에 대한 만족도가 높았 다. 그리고 유아의 기질의 적응성과 규칙성이 높고 활동성이 낮을수록 자녀의 지지에 대한 만족도가 높았다. 이러한 결과 는 아동의 생리적 규칙성과 적응성이 높고 활동성이 낮을 때 어머니의 부모역할에 대한 만족도가 가장 높게 나타났다는 연 구결과(Y. Lee \& Jo, 2002)와 일치한다. 즉, 유아의 규칙적 기질 과 새롭거나 변화된 환경에 대한 적응적 기질은 어머니의 부 모역할에 대한 만족감을 느끼게 해주는 요소가 된다고 볼 수 있다. 또한 주의가 자주 분산되고 주변 환경에 접근성이 높은 유아의 활발한 기질은 어머니로 하여금 자녀를 위험으로부터 보호해야 할 것이 많아 자녀의 행동이나 발달을 통제하게 되 고 자녀와 함께 놀이를 하거나 돌봐야 할 것이 많기 때문에 부 모역할에 대한 만족도를 떨어뜨리게 하는 부정적인 요인으로 작용한다고 해석해볼 수 있다.

이러한 결과는 어머니의 부모역할만족도에 있어 자녀의 기 질이 중요함을 시사하고 있다. 기질은 태어날 때부터 나타나 는 선천적 측면도 있으나 불변의 것이 아니라 환경과 상호 영 향을 주고 받는다는 사실(Thomas \& Chess, 1981)을 고려해 볼 때, 어머니가 자녀의 기질을 어떻게 이해, 수용하느냐의 측면 도 중요하다. 즉, 어머니가 유아의 기질적 특성을 올바르게 이 해하고 수용한다면 부모역할만족도를 증진시킬 것이며, 나아 가 부모자녀관계와 더불어 긍정적인 아동의 발달을 기대할 수 있을 것이다. 따라서 자녀의 기질에 대한 이해와 더불어 자녀 의 기질을 수용하려는 노력이 우선적으로 필요할 것이다. 또
한 어머니의 부모역할만족도를 높이기 위해 자녀의 기질에 따 른 양육법, 자녀 양육 코칭 등의 실질적인 방법을 익힐 수 있는 프로그램을 개발하여 실시한다면 자녀 양육 과정에서 어머니 의 기쁨과 만족감을 증진시킬 것으로 여겨진다.

어머니의 부모역할만족도는 유아의 기질과 부모의 고통으 로 인한 어머니의 양육스트레스 간의 관계에서 매개효과가 나 타났다. 구체적으로 살펴보면, 어머니의 부모역할만족도의 하 위 요인인 일반적 만족도와 부모자녀관계는 유아의 적응적 기 질과 부모의 고통으로 인한 양육스트레스 간의 관계에서 각각 부분 매개를 하였다. 즉, 부모의 고통으로 인한 양육스트레스 는 유아의 적응적 기질에 의해 직접적으로 영향을 받기도 하 지만 부모역할에 대한 일반적 만족도나 부모자녀관계에 대한 만족도를 통해 간접적으로 영향을 받고 있었다. 이는 유아의 기질의 적응성이 높을수록 부모역할에 대한 어머니의 일반적 만족도나 부모자녀관계에 대한 만족도를 증가시켜 부모의 고 통으로 인한 양육스트레스를 낮출 수 있다는 것을 의미한다. 어머니의 부모역할만족도의 하위 요인인 부모역할갈등은 유 아의 적응적 기질, 활발한 기질과 부모의 고통으로 인한 양육 스트레스 간의 관계에서 각각 완전 매개를 하였다. 즉, 부모의 고통으로 인한 양육스트레스는 유아의 적응적 기질이나 활발 한 기질에 의해 직접적으로 영향을 받기보다는 부모역할갈등 에 대한 만족도를 매개로 하여 간접적으로 영향을 받고 있었 다. 이는 유아의 기질의 적응성이 높거나 활동성이 낮을수록 어머니의 부모역할갈등에 대한 만족도를 증가시켜 부모의 고 통으로 인한 양육스트레스를 낮출 수 있다는 것을 의미한다. 또한 어머니의 부모역할만족도의 하위 요인인 부모자녀관계 는 유아의 활발한 기질과 부모의 고통으로 인한 양육스트레 스 간의 관계에서 완전 매개를 하였다. 즉, 부모의 고통으로 인 한 양육스트레스는 유아의 활발한 기질에 의해 직접적으로 영 향을 받기 보다는 부모자녀관계에 대한 만족도를 매개로 하여 간접적으로 영향을 받고 있었다. 이는 유아의 기질의 활동성 이 낮을수록 어머니의 부모자녀관계에 대한 만족도를 증가시 켜 부모의 고통으로 인한 양육스트레스를 낮출 수 있다는 것 을 의미한다.

어머니의 부모역할만족도는 유아의 기질과 부모-자녀간 역기능적 상호작용으로 인한 어머니의 양육스트레스 간의 관 계에서 매개효과가 나타났다. 구체적으로 살펴보면, 어머니의 부모역할만족도의 하위 요인인 부모자녀관계와 부모역할갈 등은 유아의 활발한 기질과 부모-자녀간 역기능적 상호작용 으로 인한 양육스트레스 간의 관계에서 각각 부분 매개를 하 였다. 즉, 부모-자녀간 역기능적 상호작용으로 인한 양육스트 
레스는 유아의 활발한 기질에 의해 직접적으로 영향을 받기도 하지만 부모자녀관계나 부모역할갈등에 대한 만족도를 매개 로 간접적으로도 영향을 받고 있었다. 이는 유아의 기질의 활 동성이 낮을수록 부모자녀관계에 대한 어머니의 만족도나 부 모역할에 대한 만족도를 증가시켜 부모-자녀간 역기능적 상호 작용으로 인한 양육스트레스를 낮출 수 있다는 것을 의미한 다. 어머니의 부모역할만족도의 하위 요인인 부모자녀관계는 유아의 규칙적 기질과 부모-자녀간 역기능적 상호작용으로 인 한 양육스트레스 간의 관계에서 완전 매개를 하였다. 즉, 부모자녀간 역기능적 상호작용으로 인한 양육스트레스는 유아의 규칙적 기질에 의해 직접적으로 영향을 받기보다는 부모자녀 관계에 대한 만족도를 매개로 간접적으로 영향을 받고 있었다. 이는 유아의 기질의 규칙성이 높을수록 부모자녀관계에 대한 어머니의 만족도를 증가시켜 부모-자녀간 역기능적 상호작용 으로 인한 양육스트레스를 낮출 수 있다는 것을 의미한다.

어머니의 부모역할만족도는 유아의 기질과 자녀의 특성으 로 인한 어머니의 양육스트레스 간의 관계에서 매개효과가 나 타났다. 구체적으로 살펴보면, 어머니의 부모역할만족도의 하 위요인인 부모자녀관계와 부모역할갈등은 유아의 활발한 기 질과 자녀의 특성으로 인한 양육스트레스 간의 관계에서 각각 부분 매개를 하였다. 즉, 자녀의 특성으로 인한 양육스트레스 는 유아의 활발한 기질에 의해 직접적으로 영향을 받기도 하 지만 부모자녀관계나 부모역할갈등에 대한 만족도를 통해 간 접적으로 영향을 받고 있었다. 이는 유아의 기질의 활동성이 낮을수록 부모자녀관계나 부모역할갈등에 대한 어머니의 만 족도를 증가시켜 자녀의 특성으로 인한 양육스트레스를 낮출 수 있다는 것을 의미한다.

이러한 결과들로 볼 때, 유아의 기질 자체보다는 자녀를 양 육하면서 느끼는 부모역할에 대한 만족도를 통해 어머니가 경 험하는 양육스트레스가 달리 나타날 수 있다는 것을 알 수 있 다. 또한 자녀를 양육하면서 느끼는 스트레스에 어머니의 부 모역할만족도가 중요한 요인으로 작용하고 있음을 확인할 수 있다. 본 연구와 동일한 변인들로 조사한 선행연구가 없어 직 접적인 비교가 어렵지만 자녀의 까다로운 기질과 양육스트레 스 요인을 매개하는 요인으로 양육효능감을 보고한 연구결과 (Y.-J. Lee, 2014), 유아의 기질과 양육행동 간의 관계에서 양육 효능감이 매개적 역할을 한다고 보고한 연구결과(M.-J. Kim et al., 2013)가 본 연구 결과를 어느 정도 지지한다고 할 수 있다. 또한 부모가 아동의 기질을 이해하고 수용할 때 적절한 기대 와 높은 만족도를 보이며 이러한 높은 만족도로 인해 자녀에 게 적합한 긍정적인 양육태도를 보일 수 있다는 연구결과(Jin,
1993)와 같은 맥락으로 이해할 수 있다. 이러한 결과를 통해 유아의 기질과 어머니의 양육스트레스 간의 관계에서 부모역 할만족도가 양육스트레스를 예측하는데 중요한 변인임을 확 인할 수 있다.

이처럼 본 연구의 결과는, 가정 내에 발생하는 아동학대의 원인중 하나가 자녀 양육에 대한 지식과 기술, 이해부족 때문 이라는 점(Pyon, 2017)을 고려할 때, 자녀의 기질적 특성에 대 한 지식과 이해가 필요함을 보여준다. 또한 유아의 기질이 양 육스트레스에 미치는 직접적인 영향뿐 아니라 자녀를 양육하 면서 느끼는 부모역할에 대한 만족도를 통해 미치는 간접적인 영향에도 주의를 기울여야 할 필요성을 제기했다. 따라서 자 녀의 기질과 어머니의 양육스트레스를 설명하는 데 있어 부모 역할만족도가 중요한 변인이며 이에 대한 심층적인 추후 연구 가 요구된다.

본 연구의 제한점과 함께 후속 연구를 위한 몇 가지 제언을 제시하면 다음과 같다. 첫째, 본 연구의 자료는 서울 및 경기지 역의 3세 5세의 자녀가 있는 어머니만을 대상으로 실시되어 모든 어머니에 대해 일반화하여 적용하기에 어렵다. 또한 연 령을 확대하여 영아, 유아, 아동에 대한 기질 연구가 필요하다. 둘째, 본 연구의 자료수집 방법에서 모든 변인을 어머니 보고 에만 의존하였다는 점에서 동일평가자로 인한 문제를 배제할 수 없으며, 응답자의 주관이나 편견이 작용했을 수 있다. 셋째, 본 연구에서 사용된 부모역할만족도의 하위요인 중 자녀를 양 육하고 부모역할을 수행해 나가면서 느끼게 되는 어려움이나 문제를 의미하는 부모역할갈등과 양육스트레스는 응답자가 유사하게 지각하여 구분하기 어려운 점이 있을 것으로 보인 다. 넷째, 본 연구에서는 적응적 기질, 활발한 기질, 규칙적 기 질 3 가지 하위요인으로 유아의 기질을 분석하였다. 유아의 기 질의 개인차를 고려할 때 더 다양한 기질적 특성으로 분류될 수 있다. 이후의 연구에서는 기질을 보다 다양하게 분류, 분석 하여 세세한 차이를 밝혀보는 것도 필요할 것으로 보인다. 또 한 기질이 환경과 상호 영향을 주고 받는 사실을 고려할 때, 유 아의 기질과 어머니의 적합도 측면에서의 연구도 함께 조사해 보는 것도 흥미로울 것이다.

이러한 제한점에도 불구하고 본 연구는 다음과 같은 몇 가 지 의의를 갖는다. 첫째, 선행연구에서는 유아의 기질 및 어머 니의 부모역할만족도와 양육스트레스 간의 영향에 관한 연구 가 거의 이루어지지 않았는데, 본 연구에서는 세 변인의 관련 성과 영향력에 대해 밝혔다. 특히, 기질에 대한 연구대상은 주 로 영아, 걸음마기 자녀로 국한되어 있다. 주양육자인 어머니 는 유아기 자녀와 밀접하게 관련된 일차적 환경요인인 점을 
고려하여, 유아의 발달에 결정적 영향을 미친다는 점에서 유 아기 자녀를 대상으로 살펴보았다는 것에 의의가 있다. 또한 어머니의 부모역할만족도에 대한 연구는 결혼만족도, 양육효 능감, 모성역할자신감과 같은 어머니의 심리적 특성에 대한 연구가 대부분으로 부모역할만족도를 살펴본 것에 의의가 있 다. 둘째, 유아의 기질 및 어머니의 부모역할만족도와 양육스 트레스 간의 영향에 대한 연구를 통해 자녀의 기질을 이해하 고 수용하려는 노력과 더불어 부모역할만족도의 증진에 초점 을 두어 어머니의 양육스트레스 감소의 방향성을 제시하였다. 본 연구결과는 기질은 태어날 때부터 나타나는 선천적 측면 도 있으나 환경과 상호 영향을 주고 받는다는 사실에 비추어 볼 때, 자녀의 기질이 타고난 것이라고 생각하며 환경의 영향 력을 과소평가하는 어머니에게 시사하는 바가 크다. 어머니의 양육스트레스는 유아의 기질과 비교하여 어머니의 부모역할 만족도의 영향력이 보다 컸다는 점에서 어머니의 양육스트레 스를 줄이기 위해 부모역할만족도에 초점을 둘 필요성을 제기 했다. 즉, 자녀의 기질로 인해 경험할 수 있는 양육스트레스는 어머니의 부모역할만족도에 따라 달라질 수 있다는 점을 발견 함으로써, 어머니의 심리적 특성이 중요한 역할을 하고 있음 을 확인하였다. 본 연구는 부모역할의 이해 및 기대와 부모로 서 느끼는 심리적 만족도의 중요성을 확인한 결과로 부모 교 육과 상담을 위한 기초자료로 활용될 수 있을 것이며, 우리사 회의 핵가족으로 자녀양육을 배울 기회가 부족해지고 있는 사 회적 변화 속에서 부모들은 자녀의 지식과 기술, 이해부족으 로 자녀를 자칫 폭력적으로 대하기 쉽다(Pyon, 2017). 따라서 자녀의 기질적 특성에 대한 지식과 이해는 자녀 학대 예방적 차원에서 도움이 될 수 있을 것으로 기대된다.

\section{Notes}

This article was presented at the 8th International Conference of the Panel Study on Korean Children.

\section{Conflict of Interest}

No potential conflict of interest relevant to this article was reported.

\section{References}

\section{In English}

Abidin, R. R. (1990). Introduction to the special issue: The stress of parenting. Journal of Clinical Child Psychology, 19(4), 298-301. doi:10.1207/s15374424jccp1904_1

Baron, R. M., \& Kenny, D. A. (1986). The moderator-mediator variable distinction in social psychological research: Conceptual, strategic, and statistical considerations. Journal of Personality and Social Psychology, 51(6), 1173-1182. doi:10.1037/00223514.51.6.1173

Berry, W. D., \& Feldman, S. (1985). Multiple regression in practice: Quantitative Applications in the Social Sciences (Series no. 07050). Newbury Park, CA: Sage. doi:10.4135/9781412985208

Bosquet, M., \& Egeland, B. (2006). The development and maintenance of anxiety symptoms from infancy through adolescence in a longitudinal sample. Development and Psychopathology, 18(2), 517-550. doi:10.1017/s0954579406060275

Coplan, R. J., Bowker, A., \& Cooper, S. M. (2003). Parenting daily hassles, child temperament, and social adjustment in preschool. Early Childhood Research Quarterly, 18(3), 376395. doi:10.1016/s0885-2006(03)00045-0

Guidubaldi, J., \& Cleminshaw, H. K. (1989). Development and validation of the Cleminshaws-Guidubaldi parentsatisfaction scale, In M. J. Fine (Ed.), The second handbook on parent education (pp. 257-277). New York: Academic Press. doi:10.1016/b978-0-08-091820-4.50016-7

Hockenberry, M. J., \& Winkelstein, W. (2004). Wong's essentials of pediatric nursing (7th ed.). New York: Mosby.

Kagan, J., Snidman, N., Kahn, V., \& Towsley S. (2007). The preservation of two infant temperaments into adolescence. Monographs of the Society for Research in Child Development. 72(2), 1-95.

Kalifa, D. B. (2013). Child characteristics and parenting hostility: Exploring the mediating effects of parental stress (Master's thesis). Retrieved from https://search.proquest.com/ docview/1517975162?pq-origsite=gscholar

Partridge, T., \& Lerner, J. V. (2007). A latent growth-curve approach to difficult temperament. Infant and Child Development, 16(3), 255-265. doi:10.1002/ icd.465

Roberts, B. W., \& DelVecchio, W. F. (2000). The rank-order consistency of personality traits from childhood to old age: A quantitative review of longitudinal studies. Psychological Bulletin, 126(1), 3-25. doi:10.1037//0033-2909.126.1.3

Rothbart, M. K., \& Bates, J. E. (2006). Temperament. In N. Eisenberg \& W. Damon (Eds.), Handbook of child psychology. Social, emotional, and personality development. (6th ed., Vol. 3, pp. 99-166). Hoboken, NJ: John Wieley \& Sons. 
doi:10.1002/9780470147658.chpsy0303

Slack, K. S., Holl, J. L., McDaniel, M., Yoo, J., \& Bolger, K. (2004). Understanding the risks of child neglect: An exploration of poverty and patenting characteristics. Child Maltreatment, 9(4), 395-408. doi:10.1177/1077559504269193

Thomas, A., \& Chess, S. (1977). Temperament and development. Oxford: Brunner/Mazel.

Thomas, A., \& Chess, S. (1981). The dynamics of psychological development. Family Relations, 30(2), 318-319. doi:10.2307/ 584150

Thomas, A., \& Chess, S. (1996). Temperament: Theory and practice. New York: Routledge. doi:10.4324/9780203766170

\section{In Korean}

Cho, B. H., \& Hyun, O. K. (1994). Parental satisfaction of Korean parents. Family and Environment Research, 32(5), 97-108.

Choi, H. A. (2008). The effects of the toddlers' and mothers' temperaments on parenting stress levels (Master's thesis). Retrieved from http://www.riss.kr/link?id=T11438393/

Jin, Y. B. (1993). The relationship between children's temperament and the level of parental satisfaction in their children (Master's thesis). Retrieved from http://www.riss.kr/link?id= T3553074/

Jo, Y. S., \& Jung, Y. S. (2000). Maternal perception of children's temperament \& parenting stress. Korean Journal of Human Ecology, 9(3), 271-282.

Jo, Y. Y. (2014). The effects of toddlers' temperament, mothers' demand for temperamental characteristics and parenting stress on parenting behavior (Master's thesis). Retrieved from http:// www.riss.kr/link?id=T13388366/

Jung, J.-N. (2016). A study on the factors related parenting stress of employed and unemployed mothers with preschoolers. Korean Journal of Human Ecology, 25(6), 665-679. doi:10.5934/kjhe. 2016.25.6.665

Kim, H. M., \& Doh, H.-S. (2004). Maternal parenting stress, efficacy, and behavior: Relations to children's social competence. Korean Journal of Child Studies, 25(6), 279-298.

Kim, J. M., \& Kim, J. (2015), The effect of mothers' depression on preschool children's development: Focusing on the mediation of home environment. Korean Journal of Human Ecology, 24(2), 159-170. doi:10.5934/kjhe.2015.24.2.159

Kim, K. H., \& Cho, B. H. (2000). An ecological approach to analysis of variables in the parenting stress of the dual-earner mothers and fathers. Korean Journal of Child Studies, 21(4), 35-50.

Kim, M.-J., Doh, H.-S., Shin, N.-N., \& Choi, M.-K. (2013). The effects of preschoolers' temperament and parenting sense of competence on mother' parenting behavior. Korean Journal of Child Studies, 34(2), 101-116. doi:10.5723/kjcs.2013.34.2.101
Kwon, M., Kim, H., Kim, N., \& Jang, J. (2006). Postpartum depression and maternal role confidence, parenting stress, and infant temperament in mothers of young infants. Child Health Nursing Research, 12(3), 314-321.

Lee, J., \& Jang, M. (2008). The mediating and moderating effects of parenting self-esteem on the relationship between parentingrole stress and depression among married women. The Korea Journal of Counseling, 9(2), 339-352. doi:10.15703/ kjc.9.2.200806.339

Lee, Y., \& Jo, G. (2002). Effects of child's temperament and social support on mother's parent-role satisfaction. Journal of Human Understanding and Counseling, 23(-), 99-120.

Lee, Y.-E., Kang, Y.-H., Park, H.-S., Hwang, E.-J., \& Moon, M.Y. (2003). Relationship of maternal perception of the infant temperament and confidence and satisfaction of maternal role. Korean Journal of Child Health Nursing, 9(2), 206-220.

Lee, Y.-J. (2014). A study on the influence of the temperament of child, parenting stress and social support on the parenting selfefficacy in employed mothers. Korea Journal of Child Care and Education, 85(-), 117-136.

Nam, H.-S. (2003). A difference of parenting stress dependent on children's temperament perceived by their mothers. The Journal of Child Education, 12(2), 121-135.

Noh, A.-M. (2008). The influences of parenting stress and selfdifferentiation on parental role satisfaction in mothers with infant (Master's thesis). Retrieved from http://www.riss.kr/ link?id=T11577802/

Noh, J. Y., \& Hwang, H. S. (2012). The effects of mothers' parenting stress and parental satisfaction on attachment formation with their children. Korean Journal of Human Ecology, 21(1), $27-$ 40.

Park, K. M. (2014). A study on determinants of mother parenting stress (Master's thesis). Retrieved from http://www.riss.kr/ link?id=T13525691/

Park, S. Y., Jun, C. A., \& Han, S. Y. (1996). Mother's parenting as related to child's temperament, mother's temperament and mother's parenting stress. Family and Environment Research, 34(4), 203-216.

Pyon, B. (2017). A neighhood-based approach for building the effective protection and prevention of child maltreatment system. Asia-pacific Journal of Multimedia Services Convergent with Art, Humanities, and Sociology, 7(1), 327-341. doi:10.14257/ ajmahs.2017.01.09

Seo, S. W., \& Lee, D. (2013). The effects of mother's marital satisfaction, couple conflict and infants' emotional temperament on mother's parenting stress. Journal of Early Childhood Education, 33(5), 279-298. doi:10.18023/kjece. 2013.33.5.012

Shin, J.-Y. (2011). Relations among child's temperament, parenting stress and parenting practices: The mediating role of 
parenting stress. Early Childhood Education Research o Review, 15(2), 291-312.

Song, S.-M., \& Song, J. (2007). A study on parenting beliefs, parental satisfaction, and child rearing stress. Korean Journal of Human Ecology, 16(5), 933-944. doi:10.5934/ kjhe.2007.16.5.933

Suh, J. H., \& Yi, S. H. (2009). The effect of child's temperament, mother's parenting style and goodness of fit on young korean children's intelligence. Journal of Early Childhood Education, 29(4), 47-71. doi:10.18023/kjece.2009.29.4.003

Statistics Korea (2007). Inguchongjosa[인구총조사]. Retrieved from KOSTAT website: http://kostat.go.kr.

Statistics Korea (2011). Inguchongjosa[인구총조사]. Retrieved from KOSTAT website: http://kostat.go.kr.

Statistics Korea (2017). Inguchongjosa[인구총조사]. Retrieved from
KOSTAT website: http://kostat.go.kr.

Statistics Korea (2017). Ingudonghyangjosa[인구동향조사]. Retrieved from KOSTAT website: http://kostat.go.kr.

\section{ORCID}

Jong Hee Choi https://orcid.org/0000-0001-8588-990X

Mi-Kyung Choi https://orcid.org/0000-0001-6026-1374
Received April 30, 2018 Revision received June 4, 2018

Accepted June 8, 2018 